Received : March 5, 2021

Accepted : August 16, 2021

Published : October 13, 2021
Homepage: http://trj.stptrisakti.ac.id/index.php/trj/index

DOI: https://doi.org/10.30647/trj.v5i2.116

Tourism Research Journal

E-ISSN:2598-9839

2021, Vol. 5 No. 2

\title{
Effect of Product Quality on Customer Satisfaction at Kopi Gowo Lippo Karawaci, Tangerang Selatan
}

\author{
Vienna Artina Sembiring \\ Trisakti School of Tourism \\ viena.artina@stptrisakti.ac.id
}

\begin{abstract}
This study aims to see the magnitude of the influence of product quality on customer satisfaction at Kopi Gowo Lippo Karawaci, South Tangerang. With the development of people's lifestyles, marketing orientation has changed. In addition, the development of the coffee business in South Tangerang causes a company to improve product quality to increase customer satisfaction. The researcher uses a simple regression analysis method with a quantitative descriptive approach, with a total of 97 consumers in Kopi Gowo Lippo Karawaci, South Tangerang. The results of this study indicate that product quality has a significant influence on customer satisfaction at Kopi Gowo Lippo Karawaci, South Tangerang because quality products have an important role in shaping customer satisfaction. The higher the quality of the product provided, the higher the satisfaction felt by the customer. When customer satisfaction is higher, it can lead to profits for the company. Kopi Gowo Lippo Karawaci, South Tangerang, should better prepare coffee drink products as a whole regarding the choice of coffee drink menu variants. Then the employees of Kopi Gowo Lippo Karawaci South Tangerang should further improve their skills in terms of speed, accuracy and become more responsive in serving consumers. Furthermore, Kopi Gowo Lippo Karawaci, South Tangerang, conducted a guest comment system, very helpful for the coffee shop to further improve the quality of coffee drinks.
\end{abstract}

Keywords: Product Quality, Customer Satisfaction 
Effect of Product Quality on Customer Satisfaction at Kopi Gowo Lippo Karawaci, Tangerang Selatan

\section{A. Introduction}

Nowadays Indonesian people are becoming more consumptive by going to cafes just to drink coffee or just chatting and making assignments, various coffee shops from large exclusive to small coffee shops that sell standard express coffee (Rahardjo et al, 2019). This business has been booming lately so that it has become a promising business for entrepreneurs, especially in coffee shops (Pramagista \& Wandebori, 2021). Coffee shops include cafes that are open 24 hours and include informal restaurants and can usually be found in hotels, but with the development of the times, there are endless demands from consumers so that the coffee shop has developed into an informal restaurant that sells snacks, drinks, and provides a place to relax, as well as a comfortable place to create tasks that are supported by the existence of a Wi-Fi network to make it easier for customers to find data that are usually located in shop houses or shopping malls (Wiastuti et al, 2020).

The purpose of a company is to meet the needs of its consumers to achieve its goals, therefore a company must try to meet the needs of customer satisfaction with good and promising product quality (Albari \& Kartika Sari, 2020). Because the survival of a company depends on consumer behavior because the company becomes an organizational medium to meet the needs and desires of consumers (Oke et al, 2016). The increasing number of business competitors, the increasing demands to improve the quality of existing products in the company (Adom et al, 2016).

Product quality is a very important factor in creating satisfaction for customers, customer satisfaction is also a factor in product quality. If a company provides good quality products, consumers will be satisfied (Razak, 2016; Rahayu et al, 2019). From this customer satisfaction, the customer will share his satisfaction with producers or service providers, customer satisfaction is the most important thing that must be considered by entrepreneurs because the success of a café can be seen from customer satisfaction and the quality of the product itself (Putra et al, 2020). Customer satisfaction can be measured by how much consumer expectations of the quality of the product presented (Ullah, 2012; Habibie et al, 2021).

One of the coffee shop brands located in Lippo Karawaci, South Tangerang, which was just started in August 2019 is Gowo Coffee. To increase customer satisfaction, even though Gowo Coffee is a coffee shop that is not too big, Kopi Gowo pays great attention to the products served for customers. Kopi Gowo provides a wide variety of coffee and non-coffee drink menu variants, coffee products including iced brown sugar latte, iced rum latte, iced mocha, iced americano, iced coffee chocolate, and various non-coffee drinks, namely iced brown sugar regal, iced regal rum, iced chocolate, iced rum choco, iced matcha.

Nowadays coffee is increasingly modernized with the phenomenon of palm sugar coffee which has recently been on the rise, therefore Kopi Gowo 
Effect of Product Quality on Customer Satisfaction at Kopi Gowo Lippo Karawaci, Tangerang Selatan

takes this phenomenon as an opportunity for the main product of Gowo Coffee. Kopi Gowo takes coffee as its main product, which is the raw material of local robusta grade one coffee beans, combined in such a way as to produce the ideal coffee taste. This study aims to determine the effect of product quality on customer satisfaction at Kopi Gowo Lippo Karawaci, South Tangerang.

\section{B. Literature Review Product}

Product is everything that can be offered to a market to be noticed, owned, used, and consumed so that it can satisfy wants and needs, product as anything that can be offered to the market to attract attention, acquisition, use, or consumption that can satisfy a wants and needs (Ling \& Mansori, 2018).

Product quality is the entire combination of product characteristics from marketing, engineering (planning), manufacturing (products), and maintenance that makes products used to meet customer expectations, product quality is the ability of an item to provide results or performance that is appropriate and even exceeds what the customer wants (Steven et al, 2019). Product quality dimensions and indicators customers always research the performance of a product, this can be seen from the product's ability to create product quality with all its specifications so that it can attract customers to make purchases of the product (Assegaff, 2016).

Product quality, there are several components which in detail can be described as follows (Kotler \& Keller, 2013): (1) Performance, is a characteristic of the operation and this product is purchased. For example speed, ease, and convenience in use; (2) Durability is related to how long the product can continue to be used; (3) Reliability, which is less likely to be damaged or fail to use; (4) Additional characteristics or features, namely secondary or complementary characteristics; (5) Conformity with specifications, namely the extent to which design and operating characteristics meet predetermined standards. For example, quality and design control; (6) Aesthetics, namely the attractiveness of a product to the five senses. For example, the uniqueness of product models and combinations, the beauty of product designs; (7) Perceived quality is the customer's perception of the overall quality or superiority of a product. Usually, the buyer prepares the quality in terms of price, brand name, advertisement, company reputation, and the country of manufacture.

\section{Customer Satisfaction}

Customer satisfaction is feelings of pleasure or disappointment that arise after comparing the performance of the product thought to the expected performance, customer satisfaction is an assessment that the product or service features themselves provide a level of fulfillment related to pleasant consumption (Elisabeth et al, 2019). Customer satisfaction is a function of 
Effect of Product Quality on Customer Satisfaction at Kopi Gowo Lippo Karawaci, Tangerang Selatan

expectations and performance, namely customer evaluation of product/service performance that matches or exceeds consumer expectations, overall consumer satisfaction has three antecedents, namely perceived quality, perceived value, and customer expectations (Almsalam, 2014). In general, consumer expectations are estimates of what customers believe about what Factors that Determine the Level of Customer Satisfaction (Rita et al, 2019).

The factors that drive customer satisfaction are as follows: (1) Product Quality Customers will be satisfied after buying and using the product if the product is good; (2) Price For sensitive customers, usually low prices are a source of satisfaction for these customers because customers will get high scores; (3) Service Quality Satisfaction with service quality is usually difficult to imitate. Service quality is a driver that has many dimensions, one of which is the popular one is Servqual; (4) Emotional Factor Customers will feel satisfied because of the emotional value provided by the brand for the product; (5) Cost and Convenience Customers will be more satisfied if it is relatively easy, comfortable and efficient in obtaining products or services (Irawan, 2015).

\section{Consumer}

Consumers are people who enjoy goods or services by buying them for immediate use, some limitations regarding consumers, namely (Nugroho \& Irena, 2017) : (1) Consumers are everyone who gets goods or services used for a specific purpose; (2) Intermediate consumer is any person who gets goods and / services to be used to make other goods/services or for trading (commercial purposes); (3) The final consumer is any natural person who gets and uses goods or services to meet personal, family and or household needs and not for retrading (non-commercial).

End consumers have the meaning of individuals who make purchases to meet their personal needs or household consumption. Industrial buyers or intermediary traders, namely industrial purchasing behavior have different motives and types of individuals who play a role in it, while an individual buyer is someone who purchases without being directly influenced by others or an individual who makes a purchase (Jisana, 2014).

\section{Customer Satisfaction Dimensions}

Dimensions of customer satisfaction very satisfied consumers will (Kotler \& Keller, 2013): (1) Remain Faithful Satisfied consumers tend to be loyal or loyal. Consumers who are satisfied with the products they consume will have a tendency to repurchase from the same producer; (2) Buy the product offered The desire to buy the products offered is because of the desire to repeat good experiences and avoid bad experiences; (3) Recommend products Satisfaction is a factor that encourages positive word of mouth communication. This matter can be in the form of recommendations to other potential customers and say 
Effect of Product Quality on Customer Satisfaction at Kopi Gowo Lippo Karawaci, Tangerang Selatan

good things about the product and the company that provides the product; (4) Willing to pay more Consumers tend to use price as a measure of satisfaction when prices are higher consumers tend to think of higher quality as well. Consumers also tend not to pay attention to competing brands; (5) Provide input Even though satisfaction has been achieved, consumers always want more, so consumers will provide input or suggestions so that their desires can be achieved.

Marketers also need to understand why and how customers feel satisfaction in purchasing products. Product quality can encourage customers to feel happy after making a purchase, if the customer is happy, the customer will feel satisfied with the product or service they get. Product quality is the totality of product characteristics which include product performance, product function, product reliability, and so on to satisfy the expected needs and desires of customers (Hasfar et al, 2020).

\section{Cafe}

The cafe has a very limited selection of foods and does not sell high alcoholic drinks, but there are beverages such as beer, soft drinks, tea, coffee, cigarettes, cakes, snacks, and so on (Jalil et al, 2015). A cafe is a great place used as a place to gather with friends and family or you can also relax to unwind after activities. The cafe is a small restaurant business that serves drinks and snacks aimed at visitors who want to relax with friends or family. The cafe can also be used as a meeting place for business people to relax and come up with ideas to cooperate with other business people or for their own business (Thahir \& Krishnapillai, 2018).

\section{Research Methodology}

This research is a descriptive research and the approach used in this research is a quantitative approach. Simple regression analysis method was used to see the effect of product quality on customer satisfaction at Kopi Gowo Lippo Karawaci, South Tangerang. The object of this research is the consumers or customers of Kopi Gowo Lippo Karawaci, South Tangerang who come to make purchases at Kopi Gowo Lippo Karawaci, South Tangerang in SeptemberDecember 2019.

The population in this study were customers who came to enjoy product quality at Kopi Gowo Lippo Karawaci, South Tangerang, totaling 3360 customers in September-December 2019. The number of samples in this study amounted to 97 respondents. The sampling technique in this study was accidental sampling, using the Slovin formula above, in this study the population (N) can be searched as follows:

$\mathrm{n}=\mathrm{N} /\left(1+\mathrm{N} \mathrm{e}^{2}\right)$

$\mathrm{n}=3360 /\left(1+3360(10 \%)^{2}\right.$ 
Effect of Product Quality on Customer Satisfaction at Kopi Gowo Lippo Karawaci, Tangerang Selatan

$$
\begin{aligned}
& \mathrm{n}=3360 /\left(1+3360(0,1)^{2}\right) \\
& \mathrm{n}=3360 /(1+3360(0,01) \\
& \mathrm{n}=3360 /(1+33,6)=3360 / 34,6=97,10
\end{aligned}
$$

\section{Result}

Table 1. Respondents by Gender

\begin{tabular}{llcc}
\hline \multirow{2}{*}{ Valid } & $\begin{array}{c}\text { Valid } \\
\text { Percent }\end{array}$ & $\begin{array}{c}\text { Cumulative } \\
\text { Percent }\end{array}$ \\
\cline { 2 - 4 } & Man & 52.6 & 52.6 \\
\cline { 2 - 4 } & Woman & 47.4 & 100.0 \\
\hline
\end{tabular}

Source: Data processed with SPSS (2021)

Based on the table and diagram above, it can be seen that the majority of visitors Gowo Coffee Lippo Karawaci, South Tangerang is male, that is $52.6 \%$ and the rest of the females was $47.4 \%$.

Table 2. Respondents by Age

\begin{tabular}{llcc}
\hline \multirow{2}{*}{ Valid } & $\begin{array}{c}\text { Valid } \\
\text { Percent }\end{array}$ & $\begin{array}{c}\text { Cumulative } \\
\text { Percent }\end{array}$ \\
\cline { 2 - 4 } & 14-20 year & 13.4 & 13.4 \\
\cline { 2 - 4 } & 21-25 year & 53.6 & 67.0 \\
\cline { 2 - 4 } & 25-30 vear & 17.5 & 84.5 \\
\cline { 2 - 4 } & > 30 year & 14.4 & 99.0 \\
\hline
\end{tabular}

Source: Data processed with SPSS (2021)

The age of consumers that the majority of visitors to Kopi Gowo Lippo Karawaci, South Tangerang are a group of consumers who are aged 21-25 years at 53.6\% because Gowo Lippo Karawaci Coffee, South Tangerang is more attractive to teenagers because of the menu. what is offered from this coffee shop can be said to follow the developments of the times which are currently popular among teenagers at their age. The number of consumers in the 14-20 year age group is $13.4 \%$. Meanwhile, for consumers in the $25-30$ year age group, it is $17.5 \%$, which means that apart from teenagers who mostly visit Gowo Lippo Karawaci Coffee, Tangerang Selatan is also in demand by this age group. For consumers in the age group $>30$ years of $14.4 \%$. 
Effect of Product Quality on Customer Satisfaction at Kopi Gowo Lippo Karawaci, Tangerang Selatan

Table 3. Respondents by Occupation

\begin{tabular}{llcc}
\hline \multirow{2}{*}{ Valid } & $\begin{array}{c}\text { Valid } \\
\text { Percent }\end{array}$ & $\begin{array}{c}\text { Cumulative } \\
\text { Percent }\end{array}$ \\
\cline { 2 - 4 } & Student & 51.5 & 51.5 \\
\cline { 2 - 3 } & Government & 4.1 & 55.7 \\
\cline { 2 - 4 } & Private Employee & 17.5 & 73.2 \\
\cline { 2 - 4 } & Entrepreneur & 10.3 & 83.5 \\
\cline { 2 - 4 } & Housewife & 6.2 & 89.7 \\
\cline { 2 - 4 } & Other & 10.3 & 100.0 \\
\cline { 2 - 4 } & Total & 100.0 & \\
\hline
\end{tabular}

Source: Data processed with SPSS (2021)

The total respondents 97 people, as much as $51.5 \%$ or 50 people work as students, $4.1 \%$ or 4 people work as civil servants, $17.5 \%$ or 17 people work as private employees, $10.3 \%$ or 10 people work as entrepreneurs, $6.2 \%$ or 6 people are professionals as housewives, $10.3 \%$ or 10 people work in other fields. So it can be concluded that the respondents who come to Kopi Gowo Lippo Karawaci, South Tangerang are teenagers.

Table 4. Validity Test

\begin{tabular}{lccc}
\hline \multirow{1}{*}{ Variable } & \multicolumn{1}{c}{$\begin{array}{c}\text { Item } \\
\text { Statement }\end{array}$} & r-statistic & r-table \\
\hline Quality Product & $\mathrm{X} 1$ & 0.982 & 0.259 \\
\cline { 2 - 4 } & $\mathrm{X} 2$ & 0.872 & 0.259 \\
\cline { 2 - 4 } & $\mathrm{X} 3$ & 0.887 & 0.259 \\
\cline { 2 - 4 } & $\mathrm{X} 4$ & 0.704 & 0.259 \\
\cline { 2 - 4 } & $\mathrm{X} 5$ & 0.752 & 0.259 \\
\cline { 2 - 4 } & $\mathrm{X} 6$ & 0.713 & 0.259 \\
\cline { 2 - 4 } & $\mathrm{X} 7$ & 0.619 & 0.259 \\
\cline { 2 - 4 } & $\mathrm{X} 8$ & 0.777 & 0.259 \\
\cline { 2 - 4 } & $\mathrm{X} 10$ & 0.827 & 0.259 \\
\cline { 2 - 4 } & $\mathrm{X} 11$ & 0.926 & 0.259 \\
\cline { 2 - 4 } & $\mathrm{X} 12$ & 0.842 & 0.259 \\
\cline { 2 - 4 } & $\mathrm{X} 13$ & 0.735 & 0.259 \\
\hline Sustomer & $\mathrm{X} 14$ & 0.819 & 0.259 \\
\cline { 2 - 4 } & $\mathrm{X} 15$ & 0.875 & 0.259 \\
\hline & $\mathrm{Y} 1$ & 0.829 & 0.259 \\
& $\mathrm{Y} 2$ & 0.767 & 0.259 \\
\cline { 2 - 4 } & $\mathrm{Y} 3$ & 0.832 & 0.259 \\
& & &
\end{tabular}

Tourism Research Journal, Volume 5 (2), 2021 
Effect of Product Quality on Customer Satisfaction at Kopi Gowo Lippo Karawaci, Tangerang Selatan

\begin{tabular}{cccc}
\hline & $\begin{array}{c}\text { Item } \\
\text { Statement }\end{array}$ & r-statistic & r-table \\
\cline { 2 - 4 } & Y4 & 0.671 & 0.259 \\
\hline $\mathrm{Y} 5$ & 0.699 & 0.259 \\
\hline $\mathrm{Y} 6$ & 0,778 & 0.259 \\
\hline $\mathrm{Y} 7$ & 0,744 & 0.259 \\
\hline $\mathrm{Y} 8$ & 0,820 & 0.259 \\
\hline
\end{tabular}

Source: Data processed with SPSS (2021)

The table above shows that all question indicators are valid, this is indicated by the value of $r$-count $>$ r-table $(0.182)$

Table 5. Reliability Test

\begin{tabular}{lccc}
\hline Variable & $\begin{array}{c}\text { Item } \\
\text { Statement }\end{array}$ & $\begin{array}{c}\text { Cronbach's } \\
\text { Alpha }\end{array}$ & $\begin{array}{c}\text { Alpha } \\
\text { Value }\end{array}$ \\
\hline $\begin{array}{l}\text { Quality } \\
\text { Product }\end{array}$ & $\mathrm{X} 1$ & 0.857 & 0.60 \\
\hline $\begin{array}{l}\text { Customer } \\
\text { Satisfaction }\end{array}$ & $\mathrm{X} 2$ & 0.724 & 0.60 \\
\hline
\end{tabular}

Source: Data processed with SPSS (2021)

The table above shows that all question indicators are reliable, this is indicated by Cronbach's alpha value $>$ alpha value $(0.60)$.

Table 6. Determination Coefficient

\begin{tabular}{cccc}
\hline $\mathrm{R}$ & $\begin{array}{c}\mathrm{R} \\
\text { Square }\end{array}$ & $\begin{array}{c}\text { Adjusted } \\
\mathrm{R} \text { Square }\end{array}$ & $\begin{array}{c}\text { Std. Error of } \\
\text { the } \\
\text { Estimate }\end{array}$ \\
\hline $.574^{\mathrm{a}}$ & .330 & .323 & 2.81487 \\
\hline
\end{tabular}

Source: Data processed with SPSS (2021)

The coefficient of determination $(\mathrm{R})$ test is used to determine how much the ability of the independent variable to explain the independent variable. Following are the results of respondents' assessments regarding the relationship of product quality to customer satisfaction at Kopi Gowo Lippo Karawaci, South Tangerang. The value of $\mathrm{R}$-square is 0.330 , meaning that $33 \%$ of customer satisfaction is explained by the variable of product quality, while $67 \%$ of satisfaction is influenced by other variables not examined in this study. Examples 
Effect of Product Quality on Customer Satisfaction at Kopi Gowo Lippo Karawaci, Tangerang Selatan

include customer loyalty, service quality, location, marketing mix, price, and others.

Table 7. T-Test

\begin{tabular}{|c|c|c|c|c|c|}
\hline \multirow[t]{2}{*}{ Model } & \multicolumn{2}{|c|}{$\begin{array}{c}\text { Unstandardized } \\
\text { Coefficients }\end{array}$} & $\begin{array}{l}\text { Standardized } \\
\text { Coefficients }\end{array}$ & $\mathrm{t}$ & Sig. \\
\hline & B & Std. Error & Beta & & \\
\hline$(\mathrm{Co}$ & 14.692 & 2.695 & & 5.4 & .000 \\
\hline Quality Product & .301 & .044 & .574 & 6.836 & .000 \\
\hline
\end{tabular}

Source: Data processed with SPSS (2021)

The results of the calculation of the T-test obtained a T-count of 6.836 with a significant level of 0.000 and a T-table value of 1.985 . It can be interpreted that $\mathrm{t}$-count $6,836>\mathrm{t}$-table 1,985 with a significant level of $0,000<$ 0.005. So it can be concluded that $\mathrm{H}_{0}$ is rejected and $\mathrm{H}_{\mathrm{a}}$ is accepted, which means that there is a significant influence between the Product Quality variable on Customer Satisfaction at Kopi Gowo Lippo Karawaci, South Tangerang.

\section{E. Discussion}

Product quality has a significant influence on customer satisfaction because product quality has an important role in shaping customer satisfaction. The higher the quality of the product provided, the higher the satisfaction felt by the customer. When customer satisfaction is higher, it can lead to profits for the company (Afnina \& Hastuti, 2018). Quality has a direct impact on the performance of a product or service. Therefore, quality is closely related to value and customer satisfaction. In a narrow sense, quality can be defined as being free from damage. But most customer-centric companies go far beyond this narrow definition. Instead, they define quality based on value creation and customer satisfaction. Quality is the totality of features and characteristics of a product or service that depend on its ability to satisfy stated or implied needs (Lee et al, 2014). This is a customer-centric definition. A seller has delivered quality when his product or service meets or exceeds customer expectations. Companies that meet most of the needs of their customers over time are called quality companies. This study research conducted by Razak (2016), Albari (2020), Ling \& Mansori (2018) and Sitanggang, et al (2019) that product quality has a significant effect on customer satisfaction.

\section{F. Conclusion}

Product quality is the overall characteristics of a product that can meet customer needs customer expectations. When the company can provide or offer quality products, the company will be able to create customer satisfaction. A customer will feel satisfied usually because of the experience of purchasing a

Tourism Research Journal, Volume 5 (2), 2021 
Effect of Product Quality on Customer Satisfaction at Kopi Gowo Lippo Karawaci, Tangerang Selatan

product that is consumed or used. Product quality has an important role in influencing customer satisfaction and forming customers to be loyal to the products offered by the company. The customer is an expression of a customer's feelings that are described after comparing what is expected with what the company offers.

Suggestions in this study are (1) Kopi Gowo Lippo Karawaci, South Tangerang should better prepare coffee drink products as a whole regarding the choice of coffee drink menu variants to make it more attractive so that consumers are interested in making purchases; (2) Employees of Kopi Gowo Lippo Karawaci, South Tangerang must further improve their skills in terms of speed, accuracy to be more responsive in serving consumers so that consumers will not have to wait long; (3) Kopi Gowo Lippo Karawaci, South Tangerang has a guest comment system, it will help the coffee shop to further improve the quality of coffee drinks to meet customer satisfaction.

\section{REFERENCES}

Adom, A. Y., Nyarko, I. K., \& Som, G. N. K. (2016). Competitor Analysis in Strategic Management: Is it a Worthwhile Managerial Practice in Contemporary Times?. Journal of Resources Development and Management, 24: 116-127.

Afinina., \& Hastuti, Y. (2018). Pengaruh Kualitas Produk terhadap Kepuasan Pelanggan. Jurnal Samudra Ekonomi dan Bisnis, 9(1): 21-30.

Albari., \& Kartikasari, A. (2020). The Influence of Product Quality, Service Quality and Price on Customer Satisfaction and Loyalty. Asian Journal of Entrepreneurshi[ and Family Business, 3(1): 49-64.

Almsalam, S. (2014). The Effects of Customer Expectation and Perceived Service Quality on Customer Satisfaction. International Journal of Business and Management Invention, 3(8): 79-84.

Assegaff, S. (2016). The Effect of Service Quality to Customer Satisfaction by Using Internet Banking Service in Jambi. The Asian Journal of Technology Management, 9 (1): 21-36.

Elisabeth, D. R., Nasir, A., \& Suyono, J. (2019). The Effect of Service Quality on Customer Satisfaction at Koperasi Karyawan PT. Lotus Indah Textile Industry. IJEBD (International Journal of Entrepreneurship and Business Development, 2(2): 172-178.

Habibie, F. H., Mustika, A., Ratnaningtyas, H., \& Noveti, V. (2021). Promotion of Instagram and Purchase Intention: A Case of Beverage Business at Covid-19 Pandemic. (TRJ) Tourism Research Journal, 5(1): 78-96.

Hasfar, M., Militina, T., \& Achmad, G. N. (2020). Effect of Customer Value and Customer Experience on Customer Satisfaction and Loyalty PT. Meratus

Tourism Research Journal, Volume 5 (2), 2021 
Effect of Product Quality on Customer Satisfaction at Kopi Gowo Lippo Karawaci, Tangerang Selatan

Samarinda. International Journal of Economics, Business and Accounting Research (IJEBAR), 4(1): 84-94.

Irawan, H. (2012). Indonesian Customer Satisfaction: Membedah Strategi Kepuasan Pelanggan Merek Pemenang ICS A. Jakarta: PT Alex Media Komputindo.

Jalil, N. A. A., Fikry, A., \& Zainuddin, A. (2016). E-Atmospheric Effects On Youth Intention To Revisit A Cafe. Procedia Economics and Finance, 37: $497-$ 503

Jisana, T. K. (2014). Consumer Behaviour Models: An Overview. Sai Om Journal of Commerce \& Management, 1(5): 34-43.

Kotler, P., \& Keller, K. L. (2016). Marketing Management. New Jersey: Pearson Pratice Hall.

Lee, J-Y., Sridhar, S., Henderson, C. M., \& Palmatier, R. W. (2014). Effect of Customer-Centric Structure on Long-Term Financial Performance. Marketing Science: 1-19.

Ling, C. H., \& Mansori, S. (2018). The Effects of Product Quality on Customer Satisfaction and Loyalty: Evidence from Malaysian Engineering Industry. International Journal of Industrial Marketing, 3(1): 20-35.

Nugroho, A. R., \& Irena, A. (2017). The Impact of Marketing Mix, Consumer's Characteristics, and Psychological Factors to Consumer's Purchase Intention on Brand "W" in Surabaya. iBuss Management, 5(1): 55-69.

Oke, A.O., Kamalshotiros, P., Yewande, P., Ajagbe, M. A., \& Olujobi, O. J (2016). Consumer Behavior towards Decision Making and Loyalty to Particular Brands. International Review of Management and Marketing, 6(S4): 43-52.

Pramagista, A., \& Wandebori, H. (2021). Propose Business Strategy for Coffee Shop in Indonesia (XYZ Company). European Journal of Business and Management Research, 6(1): 90-96.

Putra, A.N., Anantadjaya, S. PD., Nawangwulan, I. M. (2020). Customer Satisfaction as A Result of Combination of Food Display \& Quality. Journal of Management and Business, 19(2): 23-43.

Rahardjo, B., Hasbullah, R., \& Taqi, F. M. (2019). Coffee Shop Business Model Analysis. IJBE (Integrated Journal of Business and Economics), 3(2): 140-152.

Rahayu, N., Prasetia, R., \& Priyanto. (2019). The Effect of Service Quality on Customer Satisfaction in JKT48 Theater. Tourism Research Journal, 3(1): 8699.

Razak, I. (2016). The Impact of Product Quality and Price on Customer Satisfaction with the Mediator of Customer Value. Journal of Marketing and Consumer, 30: 59-68.

Rita, P., Oliveira, T., \& Farisa, A. (2019). The impact of e-service quality and customer satisfaction on customerbehavior in online shopping. Heliyon, 5: $1-14$. 
Effect of Product Quality on Customer Satisfaction at Kopi Gowo Lippo Karawaci, Tangerang Selatan

Sitanggang, J. W., Sinulingga, S. S., \& Fachrudin, K. A. (2019). Analysis Of The Effect Of Product Quality On Customer Satisfaction And Customer Loyalty Of Indihome ATPT Telkom Regional 1 Sumatera, Medan, North Sumatra, Indonesia. American International Journal of Business Management (AIJBM), 2(3): 26-37.

Steven, W., Purba, T., Budiono, S., \& Adirinekso, G. P. (2021). How Product Quality, Brand Image and Price Perception Impact on Purchase Decision of Running Shoes?. Proceedings of the International Conference on Industrial Engineering and Operations Management. 1289-1297.

Thahir, S. B., \& Krishnapillai, G. (2018). How does the Ambience of Cafe Affect the Revisit Intention Among its Patrons? A S on the Cafes in Ipoh, Perak. Matec Web Conferences 150: 1-16.

Ullah, S. (2012). Customer Satisfaction, Perceived Service Quality and Mediating Role of Perceived Value. International Journal of Marketing Studies, 4(1):68-76

Wiastuti, R. D., Lestari, N., \& Mulyaningrum, N. (2021). The Coffee Shop Experience For All. PalArch's Journal of Archaeology of Egypt/ Egyptology, 17(7): 2850-2863. 